to start general degree courses in some combination of science and technology ; metallurgy, wood technology, agricultural engineering and industrial chemistry are cited as examples. The Government accepts the Commission's proposal for the establishment of an Institute of African Studies, based on the University of Ghana, but having some measure of autonomy. The future of the College of Business Management at Achimota remains uncertain, and the National Council will examine ways of associating the College and also the Ghana School of Law with the Universities. The Commission welcomed the suggestion made by Prof. Carl Iversen, vice-chancellor of the University of Copenhagen, that the Government of Denmark might be willing to associate itself with a scheme for establishing further residential adult colleges in the various regions of Ghana.
In addition to the main proposal that the Colleges at Legon and Kumasi should become independent Universities, the Commission has recommended that a University College of Cape Coast be established. This College would be in some relationship with the University of Ghana, though few of the details have been worked out.

As one phase of the development of higher education in Ghana ends and another begins, the Government has paid tribute to the encouragement and practical assistance given to the Colleges by the University of London, the Inter-University Council for Higher Education Overseas and the Council for Overseas Colleges of Arts, Science and Technology. It records with satisfaction the high standards already achieved by the Colleges and its confidence in their future as independent Universities.

\title{
OBITUARIES
}

\section{Dr. Otto Maass, C.B.E., F.R.S.}

Dr. Oтto MaAss, one of the most eminent of Canadian chemists, died in Montreal on July 3 at the age of seventy. As assistant to the President of the National Research Council during the war years, director of chemical warfare in the Department of National Defence and later as scientific adviser to the Chief of General Staff, he was well known to a multitude of colleagues in both the United Kingdom and the United States. As general director of the Pulp and Paper Research Institute of Canada, he had a wide acquaintance in the pulp and paper industry. But he is best and most affectionately remembered by the many generations of graduate students who gained their first insight into the significance of physical chemistry and the meaning of chemical research under his stimulating guidance.

Otto Maass was born in New York City on July 8 , 1890 , but went to Montreal with his parents at an early age. He was educated in Montreal High School and McGill University, obtaining the B.A. degree in 1911 and the M.Sc. in 1912. He was awarded. an 1851 Exhibition scholarship and went to Berlin in 1913 to work in the laboratory of Prof. Walther Nernst. Trapped in Germany by the outbreak of war in the following year, he was able to escape across the border into Switzerland and thence return home. His interrupted studies were continued at Harvard under the late Prof. T. W. Richards. He submitted a thesis and received the Ph.D. degree from Harvard in 1919.

In 1917 he was appointed lecturer in physical chemistry at McGill. In 1923 he became Macdonald professor of physical chemistry and, in 1937, chairman of the Department, appointments which he occupied until his retirement in 1955 .

From the very outset of his teaching career, he began to be surrounded by a rapidly expanding group of enthusiastic young graduate students eager to share in the development of his ideas. One very early achievement was the preparation, for the first time, of pure hydrogen peroxide ; and this gave rise to a whole series of publications reporting accurate measurements of its physical properties. Another early investigation involved devising a simple and accurate method of measuring densities of condensable gases. This was ultimately refined to the point where reliable figures for the atomic weights of carbon and sulphur were obtained from the molecular weights of carbon dioxide and sulphur dioxide. Meanwhile, similar techniques had been applied to observe density changes on mixing two gaseous components and to detect reaction between two components in the vapour phase. This led on to a comparison of reaction velocities below and above the critical temperature which, in turn, gave rise to the prolonged series of investigations of critical phenomena which brought about a wholesale revision of ideas concerning the critical region.

As early as 1920, Maass became aware that very few reliable physical data were available on sulphur dioxide solutions such as were used in the manufacture of sulphite pulp. Work in this field was followed by a series of investigations of the factors influencing the rate of penetration of sulphite solutions into wood chips. In 1928 the Pulp and Paper Research Institute of Canada was founded, and by arrangement with the Graduate Faculty of McGill, Maass and his students were enabled to pursue further researches in the laboratories of the Institute. $\mathrm{He}$ became its general director in 1940 and was instrumental in initiating a variety of investigations of problems directly concerned with the war effort.

On his retirement in 1955 , Maass was appointed a principal research officer in the Division of Chemistry, National Research Council, and he spent the next three years in the laboratories of the Council in Ottawa. Then he returned once more to McGill as a research associate in the Chemistry Department. Much of his time was spent in his laboratory in the Chemistry Building up to the day of his death.

Space does not permit even a bare enumeration of the degrees, medals, memberships of learned societies and other honours which came to him. It would seem, in any event, superfluous to those who knew him. His work was his life and brought with it its own reward. By his work he will be remembered.

J. H. Mennie

\section{Prof. R. F. Naylor}

Ralph Francts Naylor, professor of chemistry in the Royal College, Nairobi, was killed in a motor accident at Mkushi in Northern Rhodesia on August 6. In this tragic accident, at the regrettably early age of thirty-nine, one who has done much for 
chemistry and for university education generally in East Africa was lost.

Born in 1921 in London, Ralph Naylor was edu. cated at Emanuel School and at the Imperial College of Science and Technology, London, where he graduated B.Sc. with honours in 1942. He then joined the British Rubber Products Research Association where he worked on olefinic reactivity and aliphatic sulphur compounds. Some twelve publications on this work resulted, including one in Nature, over the period 1943-1949.

In 1949 he went to Makerere College as a lecturer in organic ehemistry and became a senior lecturer three years later. In September 1953 he was given nine months leave of absence to work with Dr. J. H. Hanks in the Department of Bacteriology and Immunology at Harvard, in which he was assisted by Smith-Mundt Research and Fulbright Travel Grants. He returned to Makerere as acting head of the Chemistry Department. The head of Department, Prof. Tenniswood, had died shortly before, also in a motor accident. He acted in this capacity for nearly two years. Although one of the new chemistry buildings had just been completed, much of the design of the second building and the planning for future expansion, which he performed enthusiastically and in masterly fashion, fell to him.

In spite of these increased responsibilities, Naylor continued his research on the chemotherapy of leprosy drugs. He took much interest in leper colonies and villages throughout Uganda and neighbouring territories. He was on the Board of Governors of the Kumi Leprosy Settlement, which he visited regularly. Having decided that a radiochemical approach to this problem was likely to be fruitful he spent most of one long vacation at Harwell learning tracer techniques, so that he might design and equip a radiochemical laboratory in the Chemistry Department at Makerere. He read a paper on his work at the seventh International Congress on Leprosy in Tokyo in 1958.

The East Africa Section of the Royal Institute of Chemistry held its first annual general meeting early in 1956. Ralph Naylor was one of those responsible for its foundation. He became the Section's first secretary, and up to the time of his death he never relaxed in arranging, organizing and reporting meetings, visits, excursions and exhibitions. East African chemists owe him a particular debt in this connexion.

At Makerere he always took an active personal interest in students and student affairs, particularly in his own tutorial group. He was for a time a resident tutor, and later deputy warden of Mitchell Hall, one of the student halls of residence. He was much sought after as a lucid lecturer, an enthusiastic committee member and an impartial chairman. Ralph Naylor was a man of deep religious conviction. $\mathrm{He}$ was the founder leader of a Boys' Crusader Bible Class in Kampala, and also for some years secretary of the Uganda auxiliary of the British and Foreign Bible Society.

His interest in open-air activities was shown by his love of travel and mountain climbing. He was for a time president of the Uganda Mountain Club, and had made ascents of several of the difficult Ruwenzori peaks as well as other mountains in East Africa. He was also a trustee of the East Africa Outward Bound organization, which has its headquarters at Loitokitok at the base of Kilimanjaro, and carries out its activities on that mountain. He had also been president of the Uganda Amateur Athletic Association at the time when Uganda was beginning to play a part in international athletics. Photography was one of his hobbies.

In 1955 he married Miss Dilys Rees. She was slightly injured in the accident through which he died, and their son Paul, aged four, rather more seriously.

In January 1961 he took up duty as first professor of chemistry at the Royal College, Nairobi, and in his short time there he was also dean of the Faculty of Science, and worked enthusiastically on the planning of the new chemistry building. It is sad that he will not now see the building through to final completion and occupation.

It will thus be clear that Ralph Naylor was characterized by the energy which he put into so many diverse activities, and the thoroughness with which he carried them out. He took a pride in meticulous planning down to the finest detail and his plans nearly always succeeded. His loss will be felt by his many friends and by all who have an interest in scientific education and development in East Africa.

Malcolm Crawford

\section{Sir Arthur Olver, C.B., C.M.G.}

WrTH the death on August 15 of Sir Arthur Olver at the age of eighty-six, the veterinary profession has lost one of its most eminent authorities on livestock development. The son of a successful Cornish livestock breeder, he was early introduced to the exactions of animal husbandry. After studying in London and becoming a member of the Royal College of Veterinary Surgeons, of which he later became a Fellow, he was commissioned in the Army Veterinary Department some months before the outbreak of the South African War.

He saw active service with the cavalry, and later, as senior veterinary officer, Natal, first showed his flair for administration.

In 1904 he obtained permission to work under Theiler at his Daspoort laboratory when that authority was so successfully competing with the prevalent epizootics, as well as demonstrating with exactness connexions between nutrition and disease. In 1906 , while still a captain, he was appointed principal veterinary officer, Egyptian Army and the Sudan Civil Service. In his first year he stamped out rinderpest in the Nile Valley, organized the Sudan Veterinary Service and enabled the cattle trade between Central Africa, the Sudan and Egypt to be reorganized on a satisfactory basis, for which he was awarded the Order of Osmanieh, 4th class.

He then was appointed assistant director general, Army Veterinary Service, at the War Office. For the greater part of the First World War he served at headquarters of the British Expeditionary Force and besides being mentioned in dispatches four times was made a C.M.G. In 1917 he was sent to re-organize the veterinary arrangements of the Remount Com. mission in the United States and Canada, where equine infectious diseases were causing havoc. Once again his efforts were successful and he was made a C.B.

In 1930, when a colonel, he retired from the Army to become animal husbandry commissioner with the Government of India, an appointment which had been created on the recommendation of the Royal Commission to investi rate the state of agriculture in India. During his eight years in that office he brought under centralized supervision all aspects of official 